\title{
THE DUAL LABOUR MARKET THEORY AND THE INFORMAL SECTOR IN SOUTH AFRICA ${ }^{1}$
}

\author{
MD Uys, UNISA \& PF Blaauw, University of Johannesburg
}

\begin{abstract}
Purpose of the paper: The purpose of this paper is to revisit the dual labour market theory as far as the informal sector in South Africa is concerned. The hypothesis is that the dual labour market theory must be extended in order to be applicable to the informal sector of the South African economy. It is our view that within some informal occupations a further segmentation exists.
\end{abstract}

Problem investigated: Among South Africa's grave socio-economic problems, unemployment is one of the most serious and intractable. An increase in informal and self-employment was experienced during the last decades. Traditional dual labour market theory maintains that jobs can be roughly divided into two groups: those with low wages, bad working conditions, unstable employment and little opportunity for advancement; and those with relatively high wages, good working conditions and opportunities for advancement. The problem that confronts researchers is that even within informal employment, further segmentation is possible.

Approach: To determine whether the dualism, that described by the dual labour market theory, is also present within the informal sector itself, available data on a typical informal sector activity, namely car guarding, is analysed. This provides the evidence to achieve the objective of this paper.

Findings and implications: The case study of car guards confirms that the dual labour market theory can also apply within the informal sector on the condition that it is expanded to make provision for a further segmentation of the periphery sector. This finding presents several important policy implications. A basket of policies is needed to address the problem of unemployment as effectively as possible.

Value of the research: The paper provides further knowledge on informal employment in South Africa. This is an area that requires a lot of attention, given the importance of the informal sector in South Africa and Africa at large. It goes further than the traditional implications stemming from the dual labour market theory.

Conclusion: The South African labour market is fragmented, consisting of a well-paid formal sector and the periphery that consists of workers in the informal sector, subsistence agriculture and the unemployed. Within the periphery, there is the possibility that a certain degree of dualism exists. The case study of car guards confirms that the dual labour market theory can be extended to make provision for this dualism, even within the informal sector.

Key words and phrases: dual labour market theory; informal sector; informal employment

\section{INTRODUCTION}

Among South Africa's grave socio-economic problems, unemployment is one of the most serious and intractable. It is the greatest single cause of deep poverty, it has replaced race as the major factor in inequality, and it underlies or contributes to a wide range of other socio-economic ills (Schlemmer \& Levitz, 1998:1). In the literature, one finds different theories concerning employment and unemployment (e.g. the orthodox view, the job-search model, the natural-rate theory and the nonaccelerating inflation rate of unemployment or Nairu, and the dual labour market theory). Economic dualism refers to an organisational structure of capital into two distinct economic sectors. These two sections are described by referring to it as the 'centre' and 'periphery' respectively. The informal sector is located in this 'periphery' (Bhorat, Leibbrandt, Maziya, van der Berg \& Woolard, 2001:10). Although many different definitions of the informal sector exist, Statistics South Africa uses the following definition of informal sector employment, namely: “...unregistered business, run from homes, street pavements or other informal arrangements” (Statistics South Africa, 2003:xiii).

\footnotetext{
${ }^{1}$ A previous version of this paper was delivered at the $1^{\text {st }}$ annual Conference of the Faculty of Management, University of Johannesburg, 29 - 31 October 2006, Bunting Road Campus, University of Johannesburg. The authors appreciate the valuable comments of Prof T Contogianis, Dr C Schoeman and an anonymous referee. The usual disclaimer applies.
} 
Informal employment in South Africa, as well as in the rest of the world, comprises diverse activities. These include street trading and hawking, the provision of 'street services' such as shoe-repair and hairdressing, the provision of transport services such as taxis, as well as productive activities like manufacturing (Muller, 2003:20-21). Since 1995, these services have been extended to include car guard services at shopping centers and other public places in the central business districts of metropolitan areas (Kitching, 1999:1-3). The weakness of the informal sector lies in its concentration on retailing and personal services, its lack of craft skills, and resultant weakness in value-added production (Schlemmer \& Levitz, 1998:7). In spite of the fact that the informal sector cannot yet be regarded as a dynamic alternative for formal sector employment, it has seen tremendous growth in Africa and other developing countries during the past decades (Mulinge \& Munyae, 1998:41). The average size of the informal sector as a percentage of Gross Domestic Product (GDP) in Africa for 1999/2000 was 42 percent (Schneider, 2002:5). South Africa is no exception in this regard as illustrated below.

Figure 1 compares growth in informal sector employment compared with the corresponding decline in formal sector employment from 1970 to 2002 in South Africa.

Figure 1: Formal and informal employment in South Africa 1970 - 2002

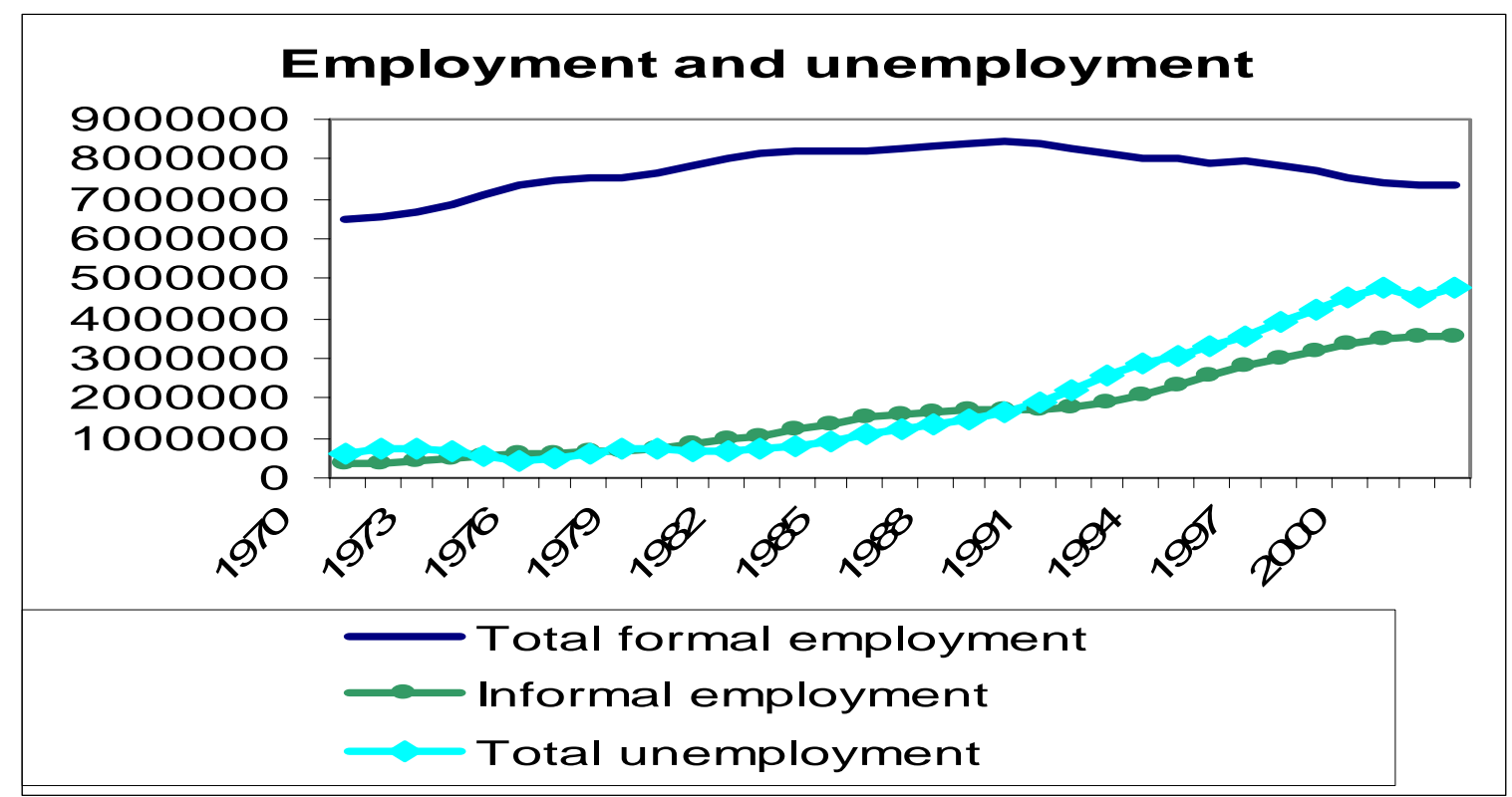

Source: United Nations Development Programme (UNDP), 2003.

Many workers who are not able to find employment in the formal sector of the economy can expect to find an income from work in the informal sector (Hofmeyr, 1998:1;6). Figure 1 shows that employment in the formal sector has shown a steady decline during the last decade under review. Schneider (2002:44) points out that there are a number of obstacles to be overcome when measuring the size of the informal economy. This explains the differences in various efforts to quantify it. Casale, Muller and Posel (2004: 983) estimated that employment in the informal sector has grown by more than 100000 people each year, or 8 percent per annum from 1997 to 2003. This trend is confirmed by the various Labour force surveys that show an average increase in informal sector employment of 5.8 percent between 2001 and 2005 (Barker, 2007:50). Braude (2005:369) estimated that the informal sector in South Africa comprises between 7 and 12 percent of the total economy. Schneider (2002:5) on the other hand puts the size of the informal economy in South Africa as percentage of GDP for the years $1999 / 2000$ at 28,4 percent.

This segmentation of the economy has been associated with a similar segmentation of labour markets (Mulinge \& Munyae, 1998:21-22). The existence of a 'periphery' or informal economy implies that an equivalent labour market that can be termed as the 'informal labour market' must exist as well (Mulinge \& Munyae, 1998:28-29). This view is echoed by the dual labour market theory. The dual 
labour market theory maintains that jobs can be roughly divided into two groups: those with low wages, bad working conditions, unstable employment and little opportunity for advancement; and those with relatively high wages, good working conditions and opportunities for advancement (Dickens \& Lang, 1985:792). The first group forms the unprotected segment of the labour market.

This must be taken into account when a policy formulation is considered. Traditionally, proponents of the dual labour market theory suggested three main policy actions to address unemployment. First, manpower training that emphasises work habits of the workers, the development and acquiring of work skills, and the preparation of unemployed people and secondary sector workers to take up available posts in the primary sector. Although human capital factors such as more and better education reduce an individual's chance to become unemployed, it is doubtful whether this strategy alone will address the unemployment crisis faced by South Africa. Mulinge and Munyae (1998:41) therefore suggest that there is a need to revisit the standard dualistic approach with a view to incorporate the changing circumstances in the informal sector of Africa and other developing countries. This provides the background for the objective and hypothesis of this article.

Against this background, the objective of this paper is to revisit the dual labour market theory as far as the informal sector in South Africa is concerned. The hypothesis is that the dual labour market theory must be extended in order for it to be applicable to the informal sector of the South African economy. It is the authors' view that in some informal occupations a further segmentation exists, similar to the original segmentation proposed by the dualists. This hypothesis is tested by analysing the evidence provided by the car guard industry in Bloemfontein as a case study. The car guard industry acts as a good proxy for analysis, given the characteristics of this evolving industry. The characteristics of this segmentation that will be scrutinised include differences in income, mobility within this informal activity as well as other working conditions of these men. The methodology employed in the research is carried out in three sections. The first section sketches the dual labour market theory and its implications; secondly the existence of dualism in the South African labour market is highlighted. The third section examines whether the dual labour market theory should be adjusted to incorporate the changing circumstances facing informal employment in South Africa. The paper concludes with a summary and some policy implications.

\section{THE DUAL LABOUR MARKET THEORY}

\section{The Development and Empirical Testing of the Dual Labour Market Theory}

The dual labour market theory has its origin in the United States of America and was developed by institutionally oriented economists (Piore, 1969:101-122; Piore, 1970:53-69 and Doeringer \& Piore, 1971:164-183). During the late 1960s and early 1970s, a group of American labour economists, the dualists, directed the attention to the continuing poverty and unemployment among disadvantaged workers in the poorer American urban (inner city) areas, the so called "slums" or ghetto's ${ }^{2}$. Dissatisfaction with the pace of reform to explain the persistence of poverty and the unemployment problem (in spite of the efforts by politicians and programs to combat poverty) as well as the low economic participation by minorities, including women, led to the emergence of the dual labour market theory (Cain, 1976:1217-1218).

This theory postulates the existence of two separate labour markets with mobility in each market but no or limited mobility between the two. In the Doeringer-Piore formulation (Doeringer \& Piore, 1971:163-183), the two markets are stratified along two general dimensions: the characteristics of jobs and the characteristics of individuals. The two markets were not defined according to specific

\footnotetext{
$2 \quad$ This theory arose gradually out of a series of relatively casual, informal studies and qualitative impressions of certain labour markets in the USA. Four different groups were pursuing these studies over the same period of time without much contact among them in four different ghetto labour markets namely Boston, Chicago, Detroit and Harlem (Gordon, 1972: 43 44).
} 
occupations or industries but rather by a set of general features. The primary and secondary sectors of the labour market are the result of the interaction between these two main forms of stratification.

The primary sector contains the privileged members of the labour force. It is governed by an internal labour market. Relative high wages are paid; there is stable employment with good working conditions, job security and good promotion prospects, in other words, mobility along seniority tracks, equity and due process in the existence and administration of work rules and regulations (Piore, 1969: 102; 1970:55 and Doeringer \& Piore, 1971:165-169). The forming of trade unions and the protection it offers workers is a further important characteristic of primary sector employment (Doeringer, 1973:3035; Beck, Horan \& Tolbert, 1978:709; Harrison \& Sum, 1979:689 and Gordon, Edwards \& Reich, 1982:7; 225-226).

The secondary sector consists of jobs that do not possess much skill specificity. The labour pool to fill these jobs is comparatively undifferentiated, approaching a homogeneous mass of raw labour power. There is little or no on-the-job training required performing these jobs and if training is provided, it is general in nature. There is a lack of formal grievance procedures and, as a consequence, the absence of union protection. There is no codification of work rules and seniority privileges as in the case in the internal labour market of the primary sector. Moreover, the workers who fill these jobs manifest traits that are compatible with these jobs - poor work discipline, unreliability on the job, unstable work patterns, lack of punctuality and respect, inattentiveness, regular absenteeism and even petty theft from the firm. Secondary sector employment creates or reinforces these bad working habits. Wages in these jobs are low. This sector has poor working conditions, provides little job security and few promotion prospects (Piore, 1969:102; 1970:55-56; Doeringer \& Piore, 1971:165166; Harrison, 1972:690-691 and Edwards, 1975:16-20). This sector is characterised by high labour turnover, considerable variability in employment and a personal relationship between the workers and supervisors that creates the opportunity for nepotism and leads to harsh and often arbitrary discipline (Piore, 1975:126-128).

Bluestone (1970:24), Harrison (1972:689-690) and Bluestone, Murphy, and Stevenson (1973:28-29) refer to the primary and secondary sectors of the labour market as the core and the periphery of the economy respectively where firms in the core of the economy tend to offer primary jobs and to follow primary labour market practices, while firms in the periphery tend to offer secondary jobs and to follow secondary labour market practices.

Various attempts have been made to test the applicability of the dual labour market theory, mainly in the United States. Some have found evidence that roughly corresponds with the implications of the theory. These include Osterman (1975:520-521) and Rumberger and Carnoy (1980:129-130). Dickens and Lang (1985: 801) found very strong support for the basic tenets of the dual labour market theory. Other studies such as Zucker and Rosenstein (1981:880) contradicted the above. Some studies like that of Rosenberg (1975:170) concluded that the dual labour market theory can be applicable but not in a simplified manner as predicted earlier.

An example of more recent work is the one by Romanienko (2000:59-70). The author explores the historical origins of dual labour markets to investigate the claim that women and people of colour have accepted their expanded participation in secondary labour market activities and provides evidence that second-tier workers have successfully adapted under prevailing inhospitable and discriminatory labour market conditions. Several studies investigated the theory for areas such as Europe as well. These are discussed in the next paragraph.

The segmentation of labour markets has been a prominent characteristic of economic transition in Europe and Central Asia (Rutkowski, 2006:39). The informal sector has grown in size in European transition economies. In some of the low-income Commonwealth of Independent States (CIS) countries, the informal sector often accounts for the bulk of the private sector. In this respect, it is very similar to other developing countries in the world. In these countries, the informal sector is often the employer of last resort, with its growth associated with the increased incidence of casual jobs as well as with self-employment. These characteristics are similar to those of other developing countries (Rutkowski, 2006:40). 
Other studies that test the applicability of the dual labour market theory for developing countries include that of Tannen (1991). Tannen (1991:580) concluded that evidence conforming to an unsophisticated version of the theory exists in Brazil. The next section discusses the existence of a similar dualism in the South African labour market.

\section{Dualism in the South African labour market}

Dualism in the South African labour market is confirmed by Van der Berg (1992:1): "(a) major economic challenge in a less developed country such as South Africa lies in overcoming the crippling dualism between the high-productivity, high-wage modern sectors and the low-productivity subsistence sectors." Van der Berg (1992:5) divided the South African labour market in three sectors: (i) workers in the well-paid formal sector of the economy, namely the manufacturing sector, public sector as well as other industries and services (excluding domestic workers) that form part of this core sector $^{3}$; (ii) the modern marginal sectors representing the part of the economy where low wages are being paid or which is dominated by migrating labourers. These include domestic workers, commercial agriculture and the mining sector; and (iii) the periphery that consists of workers in the informal sector, subsistence agriculture and the unemployed. A large percentage of workers were active in either the core or the periphery sector of the economy. In terms of the dual labour market theory, the South African labour market is clearly divided between workers employed in the core sector (insiders) and those who are not (outsiders).

The GEAR report also emphasised that the South African labour market is highly fragmented. Unregulated, low wage employment increased significantly after the 1970s and "irregular, subcontracted, out-sourced or part-time employment on semi-formal contractual terms" became the preferred source of labour for many employers (Republic of South Africa, 1996:4).

Smit (1996:59-66) enhances this dualism phenomenon after her investigation into wage differentials between South African industries. She found significant inter-industry differentials in the manufacturing sector and that the characteristics of the high wage industries (concentrated, capital intensive and big plant sizes) differ significantly with those of the low wage industries (competitive, labour intensive and smaller plant sizes). Two types of wage differentials are simultaneously evident. There is an inter-industry gap as well as a racial wage gap. The racial wage gap is bigger for workers in the low wage industries (consisting of low-paid schooled workers, mainly whites and low paid unschooled workers, mainly blacks) compared to those in the high-wage industries (well-paid schooled workers, mainly whites and well-paid unschooled workers, mainly black people). The interindustry wage gap is also significantly bigger for black workers compared to their white counterparts.

Recent literature decomposes the South African labour force into three groups according to their access to the modern consumer economy (Bhorat et al., 2001:10). The first group are those employed in the core consumer economy. It consists of the dominant high-wage modern sectors of manufacturing, government services and other industries. The second group are those employed in the marginal modern sectors. Included here are the low wage sectors of commercial agriculture and domestic services, as well as mining. The last most vulnerable sector is the peripheral labour force. Their mere existence signifies the job scarcity in the formal sectors. Subsistence agriculture, the informal sector and unemployed are included in this group.

It can be concluded from the above literature that the South African labour market is fragmented with the clear presence of characteristics analogous to that described by the dual labour market theory. The South African labour market consists of a well-paid formal sector and the periphery that consists of workers in the informal sector, subsistence agriculture and the unemployed (Van der Berg, 1992:5; Bhorat et al., 2001:10 and Braude, 2005:402-407). To determine whether this dualism must be extended in order for it to apply within the broader informal sector of the South African economy, an analysis of available data on typical informal employment, namely car guarding, is presented in the following section.

\footnotetext{
3 The mining sector is excluded here because most workers in this sector are migrant workers who do not form part of the modern consumer community.
} 


\section{DUALISM IN INFORMAL EMPLOYMENT - AN ANALYSIS OF CAR GUARDS}

According to Kitching (1999:7), the car guard industry started as a very informal activity. Unemployed people started offering their services on an ad hoc basis in exchange for a donation, to motorists at municipal parking spaces in the central business districts (CBDs) of cities.

The last couple of years saw the evolvement of a new group of car guards. This group guards cars at sporting events, schools, hospitals, churches, restaurants and especially shopping centres. They are organised and are easily recognised by shirts or jackets, displaying the name of one or other car guard organisation. The first of these, Car Watch, was established in Durban in December 1995. These organisations maintain that they are not employing the car guards. The guards are merely hiring the equipment and jackets from the organisation. Car guards are therefore entirely responsible for their own daily income (Kitching, 1999:1-3).

Blaauw and Bothma (2003:40-44) reported on a follow-up on Kitching's study on the guard industry in Bloemfontein. Two populations were identified. One group was the informal car guards in the municipal parking areas of the central business district (CBD) in Bloemfontein. The second group was the so-called formal car guards, active mainly at the private parking areas of shopping centres in the city. Table 1 provides an analysis of some of the results of the survey. It describes the educational features and income earned of formal and informal car guards.

Table 1: Educational features and income earned of car guards in Bloemfontein: 2001

\begin{tabular}{lll}
\hline & FORMAL & INFORMAL \\
\hline School Education & $100 \%$ school attendance & $8.2 \%$ never attended school \\
& $11.4 \%$ passed grade 12 & $3.3 \%$ passed grade 12 \\
$52.3 \%$ passed grade 10 & $37.7 \%$ passed grade $1-7$
\end{tabular}

Tertiary Education

4.55\% had education at a university, None college, etc.

Other formal after

13.6\% had apprenticeship-training None

school training

Racial composition

Income per day Income per hour

\section{8\% Whites (all Afrikaans) \\ $15.9 \%$ Blacks \\ 2.3\% Coloured}

Average: R 52,40

Average: R 5,70

\section{$55.7 \%$ Blacks \\ 44.3\% Coloured}

Average: $\mathrm{R} 32,00$

Average: R 3,70

\section{Source: Adapted from 2001 survey data}

Table 1 shows that prima facie evidence exists for the presence of a further dualism in terms of the Doeringer-Piore formulation, even within the informal employment provided by the car guarding industry. Even though the characteristics of the job are exactly the same i.e. an informal employment, there is a further distinction. The human capital as well as the income derived from the activity between the two groups differs vastly.

The characteristics of the individuals doing formal and informal car guarding differ significantly in terms of education levels as well as racial composition. All respondents in the formal group indicated that they did attend school, while 8,2 percent of the informal car guards said that they never received any formal schooling. More than one in ten (11,4 percent) formal car guards passed grade 12, as opposed to only 3,3 percent informal ones. Of the formal car guards, 4,55 percent achieved a qualification at a tertiary institution, but none of the informal ones did. Of the formal car guards, 13,6 percent received formal training in the form of an apprenticeship. No informal car guards testified to 
that. The pool of human capital in the formal group therefore far exceeds that of the informal group. The racial composition of the labour force in these two activities differs even more significantly. No whites were doing informal car guarding at the time of the survey, while 81,8 percent of the formal car guards were whites.

Differences are also evident in terms of the income earned by car guards. It was determined that the average income per day in 2001 was R52,40 and R32,00 for formal and informal car guards, respectively. An informal car guard earned on average only 61 percent of the income of his/her formal counterpart in spite of performing the same task per definition. The average income per hour for formal car guards was R5,70 while informal car guards earned on average R3,70 per hour. In percentage terms, this amounts to 64,9 percent.

Mobility between the two sections of car guards is also limited by certain institutional factors. Recent developments have seen a greater degree of formalisation in the car guard industry. According to section six of the Security Officers Act (Act no. 92 of 1987), people rendering a security service are required to register as security officials with the Security Officers Board of South Africa. This is important as it goes a long way to formalise the activities of car guards if this requirement is adhered to by the various car guard organisations. This requirement acts as a barrier to entry into the formal side of the car guard industry.

The case study of car guards confirms that, even within the periphery, there is a certain degree of dualism. This is important and must be taken cognisance of when focusing on policy to address the current unemployment situation in South Africa. The following section summarises the findings and highlights some policy implications flowing from the above.

\section{CONCLUSION AND POLICY IMPLICATIONS}

The South African labour market is fragmented, consisting of a well-paid formal sector and the periphery that consists of workers in the informal sector, subsistence agriculture and the unemployed. Even within the periphery, there is a certain degree of dualism. The recognition of this can contribute to a better understanding of the structures and dynamics in the informal sector. The case study of car guards confirms that the dual labour market theory can be extended to make provision for this dualism, even within the informal sector. Differences in the income earned and possibilities of mobility between the formal and informal car guards bore testimony to this.

The formal section of car guards also displays much better schooling and other forms of human capital, but they are still involved in this typical informal sector activity. The demand side must therefore also be emphasised in any policy on unemployment in South Africa: "...unless there are more jobs in the economy, upgrading education of Africans will at best change the composition of employment in their favour." (Kingdon \& Knight, 2000:16).

Secondly, policies that systematically seek to find jobs for the unemployed in the primary sector of the economy so that their secondary sector work habits can be interrupted must be put in place. The dualists believe that, once a secondary sector worker is in the primary sector of the economy, he/she will be placed on a path of stable employment. Thirdly, the government policy must remove any discriminating practices that result in certain positions in the primary sector not being accessible for certain groups of workers.

It is the authors' view that a basket of policies, as advocated for by the Classical and Dual labour market theorists, is needed to address the problem of unemployment as effectively as possible. Merely focusing on the problem from the comfort from a single ideological chair will not suffice given the complex nature of the South African labour market and its unique characteristics. This must address both the institutional factors such as flexibility in the labour market, with specific reference to the role of small, medium and micro enterprises (SMMEs), as well as the human capital aspects such as the effective provision of appropriate training programs to provide a structural response to the challenge of workforce development in South Africa.

Finally, concerted private-public partnerships are needed to further facilitate informal sector development in South Africa to render it a more dynamic alternative to formal sector employment 


\section{REFERENCES}

Barker F. 2007. The South African Labour Market - theory and practice. $5^{\text {th }}$ ed. Pretoria: Van Schaik.

Beck EM, Horan PM \& Tolbert CM. 1978. Stratification in a dual economy: a sectoral model of earnings determination. American Sociological Review, 43:704-720.

Bhorat H, Leibbrandt M, Maziya M, van der Berg S \& Woolard I. 2001. Fighting poverty - labour markets and inequality in South Africa. Cape Town: UCT Press.

Blaauw PF \& Bothma LJ. 2003. Informal Labour Markets as a solution for unemployment in South Africa - a case study of car guards in Bloemfontein. South African Journal of Human Resource Management, 1(2):40-44.

Bluestone B. 1970. The tripartite economy: labor markets and the working poor. Poverty and Human Resources Abstracts, 5(4):15-35.

Bluestone B, Murphy WM \& Stevenson M. 1973. Low wages and the working poor. Ann Arbor, Michigan: Institute of Labor and Industrial Relations, Michigan-Wayne State University.

Braude W. 2005. South Africa: bringing informal workers into the regulated sphere, overcoming Apartheids' legacy, in Good jobs, bad jobs, no jobs - labor markets and informal work in Egypt, El Salvador, India, Russia, and South Africa under editorship of Avirgan, Bivens \& Gammage, Washington D.C.: Economic policy institute.

Cain GG. 1976. The challenge of segmented labor market theories to orthodox theory: A survey. Journal of Economic Literature, 14:1215-1257.

Casale D, Muller C \& Posel D. 2004. Two million new net jobs: a reconsideration of the rise in employment in South Africa, 1995-2003. South African Journal of Economics, 72(5):978-1002.

Dickens WT \& Lang K. 1985. A test of dual labour market theory. The American Economic Review, 75(4):792-805.

Doeringer PB. 1973. Low pay, labor market dualism, and industrial relations systems. Cambridge, Mass: Harvard Institute of Economic Research. (Discussion paper no 271.)

Doeringer PB \& Piore MJ. 1971. Internal labor markets and manpower analysis. Lexington, Mass: Heath Lexington Books.

Edwards RC. 1975. The social relations of production in the firm and labor market structure, in Labor market segmentation, under editorship of Edwards, Reich \& Gordon, Lexington, Massachusetts: DC Heath:3-26.

Gordon DM. 1972. Theories of poverty and underemployment: orthodox, radical and dual labor market perspectives. Lexington, Massachusetts: Lexington Books.

Gordon DM, Edwards R \& Reich M. 1982. Segmented work, divided workers. Cambridge: Cambridge University Press.

Harrison B. 1972. Education, training, and the urban ghetto. London: Johns Hopkins University Press.

Harrison B \& Sum A. 1979. The theory of "dual" or segmented labor markets. Journal of Economic Issues, 13(3):687-706.

Hofmeyr JF. 1998. Segmentation in the South African labour market. Potchefstroom: South African Network for Economic Research, working paper no. 15. 
Kingdon G \& Knight J. 2000. The incidence of unemployment in South Africa. University of Oxford: Centre for the Study of African Economies.

Kitching K. 1999. Die ekonomie van die motorwagbedryf: Bloemfontein as gevallestudie. Unpublished honours dissertation, University of the Free State, Bloemfontein.

Mulinge MM \& Munyae MM. 1998. The persistent growth in size and importance of the informal economy in African countries: Implications for theorising the economy and labour markets. African Sociological Review, 2(2):20-46.

Muller C. 2003. Investigating South Africa's Informal Sector: Measurement, Participation, and Earnings. Unpublished Masters Thesis, Durban: University of Natal.

Osterman P. 1975. An empirical study of labour market segmentation. Industrial and labor Relations Review, July 1975:508-523.

Piore MJ. 1969. On-the-job training in the dual labor market: public and private responsibilities in onthe-job training of disadvantaged workers, in Public-private manpower policies, under editorship of Weber, Cassell \& Ginsburg, Madison, Wisconsin: Industrial Relations Research Association:101-132.

Piore MJ. 1970. Jobs and training, in The state and the poor, under editorship of Beer \& Barringer, Cambridge, Massachusetts: Winthrop:53-83.

Piore MJ. 1975. Notes for a theory of labor market stratification, in Labor market segmentation, under editorship of Edwards, Reich \& Gordon, Lexington, Massachusetts: DC Heath:125-150.

Republic of South Africa. 1996. Growth, employment and redistribution: a macro-economic strategy. Pretoria: Government Printer.

Romanienko L. 2000. Dual labour market theory and the institutionalisation of farmers' markets: Marginalized American workers adapting to inhospitable conditions. EkonomskaIstrazivanja/Economic-Research, 13(1):59-70.

Rosenberg S. 1975. The Dual Labor Market: Its existence and consequences. Unpublished Doctoral Thesis, Berkeley: University of California.

Rumberger R \& Carnoy M. 1980. Segmentation in the U.S. labor market: its effects on the mobility and earnings of Whites and Blacks. Cambridge Journal of Economics, June 1980:117-132.

Rutkowski J. 2006. Labor market developments during economic transition, Policy research working paper 3894, Washington D.C: The World Bank.

Schlemmer L \& Levitz C. 1998. Unemployment in South Africa - the facts, the prospects and an exploration of solutions. Johannesburg: South African Institute of Race Relations.

Schneider F. 2002. Size and measurement of the informal economy in 110 countries around the world, paper presented at a workshop of Australian National Tax Centre, ANU, Canberra, Australia, July 17, 2002.

Security Officers Act. 1987. Pretoria: Government Printer.

Smit MR. 1996. Inter-industry wage differentials: the wage-gap in South Africa. South African Journal of Economics, 64(1):43-73.

Statistics South Africa. 2003. Labour Force Survey, September 2003. Pretoria.

Tannen MB. 1991. Labor markets in Northeast Brazil: Does the Dual Market Model Apply? Economic Development and Cultural Change, 39(3):567-583. 
United Nations Development Programme (UNDP). 2003. South Africa Human Development Report 2003. Cape Town: Oxford University Press.

Van der Berg S. 1992. Confronting unemployment in South Africa. Stellenbosch: Stellenbosch Economic Project. (Occasional paper no 6.)

Zucker L \& Rosenstein C. 1981. Taxonomies of institutional Structure: Dual economy reconsidered. American Sociological Review, December 1981:869-883. 